PÉTER VUKMAN, PhD, Senior Assistant Professor

Institute of History, University of Szeged

6722. Szeged, Egyetem u. 2, Hungary

vuximaxi@gmail.com

originalan naučni rad

UDK: 314.151.3-054.74:32(=163.3/.6)(439)"1948/1980" 327(497.1:439)"1948/1980"

primljeno: 3. jul 2017.

prihvaćeno: 15. novembar 2017.

DOI: 10.29362/IST20VEKA.2018.1.VUK.133-146

\title{
SOCIAL COMPOSITION AND EVERYDAY LIFE OF COMINFORM EMIGRANTS IN HUNGARY $(1948-1980)^{*}$
}

\begin{abstract}
As a consequence of the outbreak of the Soviet-Yugoslav conflict, Cominformists, or ibeovci, emigrant communities were established in the Soviet Union and in Eastern Europe, including Hungary. The emigrants took an active part in the ongoing anti-Titoist propaganda campaign but they lost their political significance after the Soviet-Yugoslav relations started to normalize after 1953. In this paper, my aim is to analyze the number, ethnic and social composition of ibeovci emigrants in Hungary, as well as their everyday life, propaganda activities and the relationship between the emigrants and the Hungarian authorities. The article is based on archival research that I carried out at Hungarian archives.
\end{abstract}

KEYWORDS: Soviet-Yugoslav conflict, Yugoslav-Hungarian relationships, ibeovci emigrants, Cominformist emigrants

As a direct but unexpected consequence of the outbreak of the SovietYugoslav conflict in 1948, Yugoslav emigrant, so-called Cominformists or ibeovci, communities were established in the Soviet Union and in its Eastern European satellite states from those political emigrants who supported the policy of Joseph Stalin against Josip Broz Tito and the Yugoslav leadership. Their collective was organized in Hungary, too, at the turn of 1948-1949. The emigrants' community in Budapest served as a useful instrument in the everyday propaganda warfare against Yugoslavia. They wrote and distributed different articles in emigrant papers, and participated in the daily radio broadcasts into Yugoslavia. However, their political activities became an impediment of the slow, gradual and time-consuming process of normalization between Hungary and Yugoslavia after 1953. Although their official political organizations were dissolved in 1954, the Yugoslav political leadership took offence at and objected to their

\footnotetext{
* My research on the history of ibeovci emigrants in Hungary was founded by the Hungarian Scientific Research Fund (OTKA PD 108386).
} 
mostly Stalinist political views and their supposed leading role in South Slavic minority organizations in Hungary as late as in the mid-1970s.

My aim in this article is to provide the reader with a detailed analysis on and highlighting many aspects of the number, social composition and everyday lives of these emigrants in Hungary. Therefore, after a short introduction to the background of the formulation of these emigrant communities, I am going to analyse the number, ethnic background and social composition of the emigrants. I am also going to put special emphasis on their everyday lives, material and language difficulties and the many challenges they had to face in Hungary. Finally, I am going to give a short summary on the lives and dilemmas of the emigrants after their official community was dissolved following Stalin's death.

\section{The Soviet-Yugoslav conflict and the arrival of the first emigrants}

As it is well-known, in early 1948 Stalin opened a "new Cold war front" - this time within the Communist movement against Yugoslavia. As tensions between the two super powers started to escalate, Stalin expected complete subordination from the leaderships of the so-called fraternal parties and strict subjection to the aims of Soviet foreign policy in the countries within his sphere of influence in Eastern Europe. The regional ambitions of the Yugoslav leaders, together with their own goals and foreign policy initiatives, overstretched the limits of Stalin's tolerance. ${ }^{1}$

The rapidly and dramatically escalating tension between the Soviet Union and Yugoslavia, and as a direct consequence, between Yugoslavia and the Eastern European countries, resulted in the complete isolation of Yugoslavia within the Communist sphere of the world. Economic blockade, military pressure and border incidents became commonplace and anti-Titoist show trials took place in Albania, Bulgaria and Hungary. Moreover, the Soviet Union and its Eastern European satellites started a vigorous psychological and propaganda campaign against Tito and the leadership of the Communist Party of Yugoslavia (CPY). For different reasons, Mátyás Rákosi and the Hungarian Workers' Party (HWP) took the lead.

However, Stalin seriously miscalculated Tito's strength and popularity. Not irrespective of the vivid resemblance of the struggle against the occupying forces in World War Two and the heroic fight of the Yugoslav partisans in the

\footnotetext{
${ }^{1}$ For the causes and consequences of the Soviet-Yugoslav conflict see: Leonid Gibianskii, "The Soviet Bloc and the Initial Stage of the Cold War. Archival Documents on Stalin's Meetings with Communist Leaders of Yugoslavia and Bulgaria, 1946-1948", Cold War International History Project Bulletin, March, (1998), 112-134; Leonid Gibianski, "The 1948 Soviet-Yugoslav Conflict and the Formation of the 'Socialist Camp' Model", in: The Soviet Union in Eastern Europe, 1945-1989, eds. by Odd Arne Westad, Sven Holtsmark and Iver B. Neumann (New York: St. Martin's Press, 1994), 26-46; Jeronim Perović, “The Tito-Stalin Split. A Reassessment in Light of New Evidence", Journal of Cold War Studies, 2, (2007), 32-63; and Svetozar Rajak, "The Cold War in the Balkans, 1945-1956", The Cambridge History of the Cold War Vol. I., eds. by Melvyn P. Leffler-Odd Arne Westad (Cambridge: Cambridge University Press, 2010), 198-220., especially from 208.
} 
collective memory and party propaganda, Tito felt himself brave enough to resist the Soviet command. However, it did not mean that the country as a whole presented a united front against the Soviet oppression. A number of people had second thoughts, and several party members, both ordinary cadres and those high in the party echelon, started to doubt the validity and sincerity of Tito's steps. The support for Stalin in particular and the Soviet Union in general was particularly high in Serbia and Montenegro, among the party members, officers of the Yugoslav People's Army (JNA) and those students who studied at the University of Belgrade. According to the latest research, at least 240 thousand members were expelled from the CPY between 1948-1963 on charges of Cominformist subversive activities. About 40-60 thousand of them were held in confinement on Goli otok and in other detention camps. ${ }^{2}$

Apart from the internal resistance, so called "revolutionary", "Cominformist" or "ibeovci" emigrant communities were established in the Soviet Union and in the Eastern European communist countries. ${ }^{3}$ The first asylum seekers arrived in Hungary immediately after the Bucharest resolution of the Cominform on 28 June 1948. One of the earliest and better known among them was Lajos Dudás, member of the Serbian - and previously the Yugoslav - parliament. He crossed the border and asked for asylum in the very first days of July 1948. ${ }^{4}$ His emigration was followed by further illegal border crossings and their official community was established in 1949.

\footnotetext{
${ }^{2}$ Ivo Banac, With Stalin Against Tito. Cominformist Splits in Yugoslav Communism (Ithaka-London: Cornell University Press, 1988), 163-221. and for the latest results of reprisals: Momčilo Mitrović, "Ibeovci u Srbiji 1948-1952. u partijskim izveštajima", in: Jugoslovensko-sovjetski sukob 1948. godine. Zbornik radova sa naučnog skupa, gl. ur. Petar Kačavenda (Beograd: ISI, 1999), 223-234; Srđan Cvetković, Između srpa i čekića. Knjiga I. Represija u Srbiji 1944-1953 (Beograd: ISI, 2006), 368-392; Idem, "Politika represije u Srbiji i Jugoslaviji 1944-1985. Pokušaj kvantifikacije i komparacije nekih parametara političke represije u Srbiji i Jugoslaviji 1944-1985", Istorija 20. veka, 2, (2008), 272-315; Idem, Između srpa i čekića 3. Oblici otpora komunističkom režimu u Srbiji 1944-1991 (Beograd: ISI, 2013), 247-249.

${ }^{3}$ For the history of ibeovci emigrants in Eastern Europe see: Petar Dragišić, "Napred - List jugoslovenskih emigranata (pristalica Kominforma) u Bugarskoj”, Tokovi istorije, 3-4, (2005), 125-142; Момчило Митровић-Слободан Селинић, "Југословенска информбироовска емиграција у источноевропским земљама, 1948-1964”, Токови историје, 1-2, (2009), 31-54; Petar Dragišić, Jugoslovensko-bugarski odnosi 1944-1949 (Beograd: INIS, 2007), 232-250; Slobodan Selinić, Jugoslovensko-čehoslovački odnosi 1945-1955 (Beograd: INIS, 2010), 355444; Ondřej Vojtěchovsky, Z Prahy proti Titovi! Jugoslovánská prosovětská emigrace v Česhoslovensku (Praha: Filozofická fakulta Univezity Karlovy, 2012). For the ibeovci emigrants in Hungary see: Vukman Péter, „Harcban Tito és Rankovics klikkje ellen” Jugoszláv politikai emigránsok Magyarországon (1948-1980) (Budapest-Pécs: ÁBTL-Kronosz, 2017), in Serbian: Péter Vukman, "Jugoslovenski politički emigranti u Mađarskoj (1948-1949)", in: Mađari i Srbi sa dve strane promenjive granice 1941-1948. Tematski zbornik radova, ur. Árpád Hornyák, Zoran Janjetović and László Bíró (Budapest: MTA BTK Történettudományi Intézete, 2016), 351-383.

${ }^{4}$ The Hungarian News Agency (Magyar Távirati Iroda) issued a short press statement on the circumstances of his emigration on 10 July 1948, two weeks after the Bucharest resolution had been made public. According to the statement, the Yugoslav secret police wanted to arrest Dudás at the meeting of the local CPY organization at Palić on 5 July, but, together with two other „Communist workers", he managed to escape with the help of fellow party members from
} 


\section{Number, ethnic background and social composition of the emigrants}

The Serbian historiography nearly unanimously considers the overall number of the ibeovci emigrants as little less than 5 thousand, about 10 per cent of which lived in Hungary (455 people to be more precise). In comparison, most of the political emigrants lived in Bulgaria and Albania (1705 and 1340 people, respectively), their number was even higher from those who lived in the Soviet Union (708 people). Hungary, together with Romania (497 people), were somewhere in the ,middle of the pack”, while only 24 emigrants were kept on file in Poland ${ }^{5}$ - probably not irrespective of the great geographical distance.

However, the Hungarian archival records never put the number of ibeovci emigrants living in Hungary so high. During my archival research, I managed to identify 132 ibeovci emigrants who belong to the emigrants' community for shorter or longer šučods between 1948 and 1953. There might be many reasons for this significant divergence. Firstly, the Yugoslav source covers a much broader period and might count all political emigrants as ibeovci between 1948-1964. However, based on the information of the Hungarian state security organs, only nine people were considered and added to the community as political emigrants after 1953. Half of them originally belonged to the collective but were expelled from it between 1949-1953 and for different reasons. For example, they were held in detention camps or served strict prison sentences until 1954/1955. Therefore, we can add only four new members to the list. (While by size more Yugoslav citizens arrived illegally in Hungary and asked for residence permit and not all former emigrants who had been expelled from their community before 1953 were readmitted, either.) ${ }^{6}$ Secondly, the Hungarian lists and reports never identified or contained the names of the wives of the emigrants - regardless of the fact

neighbouring Bački Vinogradi. The National Archives of Hungary, Budapest. (MNL OL) XXVIA-14. MTI Napi Hírek. Belpolitikai Szolgálat. 1948. július 10. 5. kiadás. [MTI Daily News, Internal Politics, 10 July $1948,5^{\text {th }}$ issue.]

${ }^{5}$ Cited by I. Banac, op. cit., 223, M. Mitrović, S. Selinić, op. cit., 34. és Momčilo Mitrović, Tri dokumenta o ibeovcima (Beograd: INIS, 2009), 35. Mitrović-Selinić also notes that according to another account written in the 1950s, there were 650 emigrants in Hungary, 1500 in Bulgaria and 250 in Czechoslovakia. M. Mitrović, S. Selinić, op. cit., 34, note 11. Based on Yugoslav archival records, Petar Dragišić estimates the number of Yugoslav emigrants in Bulgaria to approximately 800 people. P. Dragišić, Jugoslovensko-bugarski odnosi ..., 243.

${ }^{6}$ Historical Archives of the Hungarian State Security (ÁBTL) 2.1.5. O-6021/21. 148. It is also true that much more people arrived from Yugoslavia to Hungary after 1948 but they were not considered political emigrants. I guess that most of them could be ethnic Hungarians who left Yugoslavia for different reasons Many of them were afraid because of the deterioration of Yugoslav-Hungarian relations and had fears of the repetition of the atrocities of 1944-1945. They were also a Spanish and a Greek political emigrant community at the same time in Hungary. It might be worth knowing that at the same time many Hungarians crossed the border towards Yugoslavia. According to an archival source, between 1948-1952 2116 civilians and 130 soldiers emigrated from Hungary to Yugoslavia. Tito organized a political emigrant community that held its first meeting at Novi Sad in August 1952. MOL XIX-J-4-a. 12. d. p. 407. 198/2/szig. biz.-1952. 
that they married in Yugoslavia or in Hungary - or their infants. Only a few exceptions were made, for example in the case of those who belonged to the so called diplomats' group or participated in political activities. Even if we take the number of spouses and children into consideration, it cannot explain convincingly the difference between the Hungarian and Yugoslav data. Thirdly, and probably most importantly, different methodological approaches might be suggested in the background. On the one hand, based on the contemporary terminology of the Hungarian Workers' Party (HWP), only those refugees were considered to be political emigrants who (1) asked for and were granted political asylum, (2) were officially affiliated to the HWP and the emigrants' own community, and (3) lived in Budapest or in its vicinity. On the other hand, the Yugoslav state securities might have used a broader definition and they presumed that all emigrants who left Yugoslavia to Hungary after 1948 had political motives to flee the country in the case of Hungary, at least.

Moreover, there was no single moment when all 132 political refugees belonged to the same community. The fluctuation among its members was particularly high even in those periods when the total number of political emigrants increased. The vast majority of the political asylum seekers crossed the YugoslavHungarian border in the first two years of the Soviet-Yugoslav conflict. Most of them arrived in the second half of 1949 and their communities reached its peak next summer. After 1950, the number of those refugees who belonged to the political community stabilized around 75. From October 1952 to March 1953, only two new political refugees arrived in Hungary. Nearly 90 per cent of the emigrants were males; with the majority in their mid-twenties and early thirties at the time of crossing the border. Approximately three fifth of the emigrants were born between 1921-1930. The oldest among them were Dragutin Grujić (born on 7 September 1893 at Ostrovo in Serbia) and Péter Berkes (born on 30 July 1898 in Subotica), while the youngest was Ilija Vrbica who was born on 14 March 1934 at Bajmok, therefore was only 15 years old when he crossed the YugoslavHungarian border. ${ }^{7}$ They predominantly arrived in Hungary from the neighbouring Yugoslav republics.

Table 1: The number of ibeovci emigrants in Hungary

\begin{tabular}{|l|r|}
\hline Date & Number \\
\hline 24 February 1949 & 28 \\
\hline 27 January 1950 & 91 \\
\hline 13-14 May 1950 & 89 \\
\hline Summer 1950 & 102 \\
\hline 10 May 1952 & 75 \\
\hline 15 August 1952 & 74 \\
\hline 15 January 1953 & 75 \\
\hline 1 September 1953 & 74 \\
\hline
\end{tabular}

Sources (on the order of the dates in the table): MNL OL M-KS 276. f. 54. cs. 31. ö. e. 56.; 65. cs. 105. ö. e. 8-9.; 65. cs. 105. ö. e. 1.; 98. cs. 139. ö. e. 88.; 98. cs. 139. ö. e. 178.; 98. cs. 140. ö. e. 4-12. és 98. cs. 140. ö. e. 237-262.

\footnotetext{
${ }^{7}$ ÁBTL 3.1.9. V-116876. 105-106.
} 
Most of the emigrants were born in Serbia. Their absolute majority in the case of Hungary might be the combined result of the geographical proximity, the favourable flat terrain, the Hungarian minority population and the overrepresentation of Serbians among ibeovci refugees in general. However, these were far from the sole factors, and not once it was accidental who emigrated where. For example, political asylum seekers also arrived in Hungary from Macedonia, Montenegro or the Autonomous District of Kosovo-Metohija. Some of the sources, for example the autobiographical writings of the emigrants, and the records of evidence, also suggest that kinship, personal and fraternal relations played a part in the decision making. These factors could also determine whether they crossed the border individually or in smaller or larger groups and also in which country they wanted to settle. During my research, I managed to identify the exact place of birth in case of 100 emigrants:

Table 2.1: Place of birth of those ibeovci emigrants who emigrated to Hungary

\begin{tabular}{|l|l|l|}
\hline \multirow{2}{*}{ Place of birth } & \multicolumn{2}{|l|}{ IB emigrants in Hungary } \\
\cline { 2 - 3 } & number & per cent $(\%)$ \\
\hline Serbia & 53 & 53 \\
\hline Croatia & $27 / 28$ & $27 / 28$ \\
\hline Bosnia and Herzegovina & $5 / 6$ & $5 / 6$ \\
\hline Slovenia & 7 & 7 \\
\hline Macedonia & 1 & 1 \\
\hline Montenegro & 3 & 3 \\
\hline Hungary & 2 & 2 \\
\hline Austria & 1 & 1 \\
\hline Total & 100 & 100 \\
\hline
\end{tabular}

(Note: It is not possible to decide whether Boško Kolundžija was born on the Croatian or the Bosnian side of the border.)

Table 2.2: Place of birth within Serbia of those ibeovci emigrants who emigrated to Hungary

\begin{tabular}{|l|l|l|}
\hline \multirow{2}{*}{ Within Serbia } & \multicolumn{2}{|l|}{ Ibeovci emigrants } \\
\cline { 2 - 3 } & number & per cent $(\%)$ \\
\hline Belgrade & 4 & 7,5 \\
\hline Serbia proper & 7 & 13 \\
\hline Vojvodina & 40 & 75,5 \\
\hline Kosovo and Metohija & 2 & 4 \\
\hline Total & 53 & 100 \\
\hline
\end{tabular}

Some of the emigrants simply wanted to pass through Hungary and wished to settle down either in the Soviet Union (for example Boško Kolundžija intended to stay there "until there is true Marxism-Leninism in Yugoslavia"), ${ }^{8}$ or in Czechoslovakia. Their own previous secondary or tertiary education at technical schools and military academies - or those of their friends and relatives as well as the linguistic affinity between the Slavic languages could play an understandable part in their decision.

${ }^{8}$ MNL OL XIX-B-10. 26. d. 18. ő. e. Jegyzökönyv, 1948. december 18 [Minutes, 18 December 1948]. 
There was also some convergence of time when quite a lot of people emigrated in a relatively short period, for example in November 1948, March 1949, May 1949 and especially in August 1949, during which at least 16 emigrants arrived in Hungary. However, the insufficiently available archival materials make it impossible to decide whether this last leap was a consequence of the Soviet note of 18 August 1949 which the Titoist leadership feared as a ultimatum.

As for the ethnic composition of the emigrants, it is clear that Serbs were at least in relative majority both among the total number of emigrants and both among those who settled down in Hungary. (The overrepresentation of Serbs and Montenegrins in relations to their size within the total Yugoslav population had historical and political reasons.) Their share was slightly above their national average, too, while Croats were rather underrepresented. (They formed 41,5 and 24 per cent of the total Yugoslav population in 1948, respectively.) With all probability, Serbs also predominated among those refugees who were born in Croatia. It is almost certain that all those ethnic Hungarians who would be granted political asylum arrived from the autonomous territory of Vojvodina, even if the majority of Vojvodinaers were also Serbs.

Table 3: The national composition of the ibeovci emigrants in Hungary

\begin{tabular}{|l|l|l|l|l|l|l|}
\hline \multirow{2}{*}{$\begin{array}{l}\text { Ethnic } \\
\text { composition }\end{array}$} & \multicolumn{2}{|l|}{ Ibeovci emigrants in Hungary } \\
\cline { 2 - 7 } & \multicolumn{2}{|l|}{ Summer 1950} & \multicolumn{2}{l|}{ Summer 1952} & \multicolumn{2}{l|}{ Spring 1953} \\
\cline { 2 - 7 } & $\mathrm{n}$ & $\%$ & $\mathrm{n}$ & $\%$ & $\mathrm{n}$ & $\%$ \\
\hline Serb & 52 & 51 & 32 & 44 & 33 & 44 \\
\hline Croat & 18 & 17 & 13 & 18 & 14 & 18,5 \\
\hline Slovene & 5 & 5 & 6 & 8 & 6 & 8 \\
\hline Montenegrin & 10 & 10 & 9 & 12 & 10 & 13 \\
\hline Macedonian & - & & & & & \\
\hline Hungarian & 13 & 13 & 10 & 14 & 10 & 13 \\
\hline Other & 4 & 4 & 3 & 4 & 2 & 3,5 \\
\hline Total & 102 & 100 & 73 & 100 & 75 & 100 \\
\hline
\end{tabular}

As for the social composition of the emigrants, only vague remarks can be made. It is certain that most of the emigrants who settled down in Hungary originated from lower social strata. The majority of them lived in the countryside or were first generational town dwellers. Those with poor or middle peasant background were highly overrepresented while only a few came from intellectual or mercantile families. The reports of the HWP in this matter (prepared between 1950-1954) can be summarized in the following table:

Table 4. Social composition of the emigrants

\begin{tabular}{|c|c|c|c|c|c|c|}
\hline & $\begin{array}{c}\text { May } \\
1950\end{array}$ & $\begin{array}{c}10 \text { August } \\
1952\end{array}$ & $\begin{array}{c}15 \text { August } \\
1952\end{array}$ & $\begin{array}{c}15 \text { Janu- } \\
\text { ary 1953 }\end{array}$ & $\begin{array}{c}16 \text { May } \\
1953\end{array}$ & $\begin{array}{c}2 \text { April } \\
1954\end{array}$ \\
\hline worker & 35 & 10 & 24 & 19 & 19 & 13 \\
\hline $\begin{array}{c}\text { peasant (small } \\
\text { and middle) }\end{array}$ & 24 & 50 & 34 & 42 & 37 & 46 \\
\hline lower middle & 8 & 13 & 14 & 10 & 7 & $12^{9}$ \\
\hline
\end{tabular}

\footnotetext{
${ }^{9}$ Together with wealthy peasant and intellectual background.
} 


\begin{tabular}{|c|l|l|l|l|l|l|}
\hline $\begin{array}{c}\text { class, artisan } \\
\text { and retailer }\end{array}$ & & & & & & \\
\hline intellectual & 38 & & & 2 & 2 & \\
\hline $\begin{array}{c}\text { kulak (wealthy } \\
\text { peasant) }\end{array}$ & & & 2 & 2 & 1 & \\
\hline other & & & & & 9 & \\
\hline
\end{tabular}

Sources: MNL OL M-KS 276. f. 65. cs. 105. ő. e. 5.; 98. cs. 139. ö. e. 181.; 98. cs. 139. ö. e. 178.; 98. cs. 140. ö. e. 6.; 98. cs. 140. ö. e. 169.; 54. cs. 307. ő. e. 29.

To put this in a wider historical context, these facts highly resemble the industrial and social indicators of contemporary Yugoslavia. They also highly resemble the reports of the UDB, according to which, among the 4928 Yugoslav citizens who emigrated those with peasant or military background were in a dominant position (905 and 791 people, respectively), and they were followed by 503 students, and emigrants with working class or intellectual background (454 and 271 people, respectively). ${ }^{10}$ It is also the outcome of the history of interwar Yugoslavia that most of the emigrants got affiliated with the Communist movement as a teenager - though in certain individual cases, other motives could also play a part. The Second World War meant another formative experience. Participation in the partisan warfare was repetitively emphasized in nearly all surviving autobiographies. The majority of the emigrants joined the partisan movement and soon became members of the Yugoslav Communist Party, too. According to two archival sources from January and May 1950, 52-58 per cent of the emigrants were members or candidates of the CPY. (In comparison, 3 per cent of the whole population of Yugoslavia was member of the CPY at that time. ${ }^{11}$ Another common feature of the biography of the emigrants was their employment at the Yugoslav state security organizations. Based on my research, at least 20 emigrants had been employed either by OZNA, UDB or KOS before they emigrated. This was an open secret among the members and leaders of the emigrant community, too. For example, Boris Verstovšek, one of the leaders of the emigrants, mentioned in his letter signed on 10 August 1952 that ten members of the emigration had been employed by the Yugoslav political police and other state security organs, and an additional seven people had served as border patrol in KNOJ before they emigrated - from a community that had 73 members at that time. The emigrants themselves suspected that another 26 fellow members might be an informer for, or secret agent of, the Yugoslavs. ${ }^{12}$

10 Радоица Лубурић, “Југословенска информбировска емиграција између илузија и стварности (1948-1953)", Историјски записи, LXX, (1997), 4-5. and S. Cvetković, Između srpa i čekića 3, 247.

${ }^{11}$ MNL OL M-KS 276. f. 65. cs. 105. ö. e. 1. and 6; 185. ö. e. 10. and 15; and Paul S. Shoup, The East European and Soviet data handbook. Political, social, and developmental indicators, 1945-1975 (Stanford-New York: Columbia University Press, 1981), 82.

${ }^{12}$ MNL OL M-KS 276. f. 98. cs. 139. ö. e. 181. 


\section{Everyday lives, material and language difficulties}

Serious hardship was a characteristic of the everyday lives of the emigrants, too. One of the most pressing tasks was to organize their daily activities, and provide shelter and a place for employment for the new arrivals. Large differences appeared in their material, financial situations and housing conditions. While the so called diplomatic group, the elite of the emigrants, lived under near luxurious circumstances first ${ }^{13}$ and got similar wages to the highest echelons of the Hungarian party and state bureaucracy, ${ }^{14}$ other members of the rapidly and continuously expanding community suffered from almost systematic shortages in material and financial well-being and accommodation. These problems were gradually solved by the mid-1950s. Individually and collectively, the emigrants lived under at least 17 addresses in Budapest. The largest commune was at 11/B Fürj Street where 12 emigrants lived at that time. ${ }^{15}$ Some of the emigrants were accommodated in the vicinity of the Hungarian capital (for example, Budakeszi, Budaliget, Pomáz and Szentendre). The number of those emigrants who lived in communes steadily decreased. Most of the 75 emigrants who belonged to the community in January 1953 lived in lodgings or as cotenants and those who studied at different universities and colleges were sheltered in dormitories. ${ }^{16}$ Only the fate of the commune at Fürj Street remained unsolved until September $1953 .{ }^{17}$ It is also true that these hardships afflicted not only the emigrants but the general public, too. Budapest suffered serious damages during the last phase of World War Two, and the forced and extensive expansion of heavy industry resulted in serious shortfalls. In comparison, the financial and material situation of the emigrants was still at least on or above the level of ordinary Hungarians.

The emigrants also suffered from language difficulties. Only a fraction of them were ethnic Hungarians, and the majority had only slight or no knowledge in Hungarian before they emigrated. It is not surprising that some of them considered their stay in Hungary temporary in this sense, too, and wanted to move on to Czechoslovakia or the Soviet Union. The lack of Hungarian knowledge made it more difficult to find a proper workplace for them and to

\footnotetext{
${ }^{13}$ MNL OL M-KS 276. f. 54. cs. 31. ö. e. 56. and ÁBTL 2.1. IV/37-a. 27-28.

${ }^{14}$ The Hungarian authorities allocated 3 thousand Forints on a monthly base for Brankov, 2-2 thousand Forints for Ozren Krstonošić and Dušan Vidović, and 2500 Forints for Milutin Stevanović. MNL OL M-KS 276. f. 54. cs. 31. ö. e. 56. To compare, the wages of the ministerial heads of departments in January 1950 was 3850 Forints, while the under-secretaries earned 3330 Forints a month. An average worker earned 652 Forints a month (606 Forints in 1949) and the peasants 406 Forints. Honvári, János, "A hatalmi „elit” jövedelme az 50-es években”, http://archivnet.hu/gazdasag/a_hatalmi_elit_jovedelme_az_50es _evekben.html. Downloaded on 25 June 2013, and Valuch, Tibor, Magyar hétköznapok. Fejezetek a mindennapi élet történetéböl a második világháborútól az ezredfordulóig (Budapest: Napvilág, 2013), 38.

${ }^{15}$ MNL OL M-KS 276. f. 98 . cs. 141. ö. e. 23.

${ }^{16}$ MNL OL M-KS 276. f. 98 . cs. 140. ö. e. 7.

${ }^{17}$ MNL OL M-KS 276. f. 98. cs. 140. ö. e. 217., 140. ö. e. 269. and 54. cs. 307. ö. e. 25.
} 
integrate them into the wider society. It is true, however, that the Moscow centre of the emigrants considered their learning a high priority. After Pero Popivoda had drawn Rákosi's attention to this matter, 55 ibeovci emigrants were allowed to study at different colleges and universities in the autumn semester of 1952 , which meant that nearly 70 per cent of the actual community participated in higher education. ${ }^{18}$ Most of them (20 people) studied Marxism-Leninism or Russian language and literature ${ }^{19}$ - obviously partly for linguistic and partly for ideological reasons. ${ }^{20}$

In the meantime, internal conflicts, real and imagines grievances, and personal rivalries became commonplace in this rather small and closed community. The arrest and sentencing of Lazar Brankov as the tertially defendant of the Rajk-trial in September 1949 had a destructive effect on the lives of the emigrants. A climate of fear and mutual and repeated accusations became a striking feature of everyday living. Order and discipline completely decayed, everybody was afraid and suspicious of the other. They tried to resort from everyday problems and backbiting in amusements. The internal division and dissention, personal, political and ideological conflicts among the leadership of the emigrants became permanent throughout the years of existence of the political emigrants' communities. ${ }^{21}$

\section{Ibeovci emigrants in Hungary after 1953}

The history of the ibeovci emigrants did not end with Stalin's death in March 1953. The slow and prolonged process of normalization between the Soviet Union and Yugoslavia, and consequently between Yugoslavia and the other Eastern European countries ${ }^{22}$ meant a real challenge for them, both individually and as a collective. They lost justification for their further political activities after the Political Committee of the HWP had decided on 14 October 1954 to stop the further distribution of anti-Yugoslav and anti-Titoist printed materials, ceased to publish Za ljudsko zmago, and dissolved the emigrants' organization. The tone of the radio broadcasts had been attenuated, too, before they were permanently dissolved in the summer of $1955 .{ }^{23}$ All these resulted to the emigrants' further marginalization. They simply could not ignore the question whether it was worth emigrating at all. The answer must have meant a serious dilemma for most of them and, naturally, different responses were formulated.

\footnotetext{
${ }^{18}$ MNL OL M-KS 276. f. 98. cs. 144. ő. e. 57. and MNL OL M-KS 276. f. 98. cs. 144. ö. e. 11.

${ }^{19}$ MNL OL M-KS 276. f. 98. cs. 144. ö. e., 69-70.

${ }^{20}$ For the educational opportunities and language difficulties of the emigrants see: P. Vukman, "Harcban Tito and Rankovics klikkje ellen"..., 107-112.

${ }^{21}$ For the internal conflicts in detail see: Ibid., 113-119.

${ }^{22}$ For the relationship between Yugoslavia and its neighbours after Stalin's death see: Vladimir Lj. Cvetković, Pogled iza gvozdene zavese. Jugoslovenska politika prema zemljama narodne demokratije u susedstvu 1953-1958 (Beograd: INIS, 2013), 35-376.

${ }^{23}$ MNL OL M-KS 276. f. 53. cs. 198. ö. e. and MNL OL XIX-J-1-u-Sík Endre-606/S-55 (65. d.).
} 
Those emigrants who remained politically active could not and did not want to integrate into the wider society; they regarded their stay in Hungary provisional even in the early $1960 \mathrm{~s}$. Their ultimate aim remained to return to a Yugoslavia without Tito; therefore, they took an unbroken interest in and reacted vehemently to the development of Yugoslav internal and foreign affairs. They were not exempt from a certain degree of nationalism and, in this context; they considered themselves superior to local Hungarians. Many of them thought that they had made real sacrifices during the struggle against Tito, but now they started to feel that they were being left completely neglected. ${ }^{24}$

The emigrants formed many groups along their different political and ideological views, personal and fraternal relations. The largest and most important one consistently followed their assumed ideological purity and held their previous stance and Stalinist approach against the policy of Tito and the Yugoslav leadership. They retained their hardline and dogmatic views, and started to cultivate close relations with other communities of Cominformist emigrants living in the Soviet Union and in Eastern Europe. Paradoxically, these groups became politically more active from the second half of the $1950 \mathrm{~s}$, after their official organization had already ceased to exist, and reacted critically to the twists and turns of the official Soviet stance towards Yugoslavia. It was this period when the communities of the emigrants living in different countries became more and more interrelated and their relationship really became reciprocal, and in this sense, more democratic. Naturally, the internal dynamics of Soviet-Yugoslav relations and the struggle between China and the Soviet Union for the leadership of the world-wide Communist movement greatly contributed to these processes and facilitated them.

As the Soviet-Yugoslav relations again deteriorated, this time after the suppression of the Hungarian revolution, and reached its nadir in 1958, the communities of the ibeovci emigrants, both in Hungary and in other countries, once again renewed their political activities and, among other things, they were planning to establish a trans-national organization that would incorporate all their communities in whichever countries they may have lived and would have served as the real Communist Party of Yugoslavia. According to some confidential information from the Czechoslovak state security organization, the statutory conference of the emigrants was held in Hungary in the strictest confidence in Pécs, between 27 and 28 June 196012 delegates participated altogether from the Soviet Union, Romania, Bulgaria, Czechoslovakia and Hungary. However, the Hungarian secret police refuted the information mentioned above; they had absolutely no information about the conference or about establishing a new emigrant organization. ${ }^{25}$

However, Khrushchev's real aim from the beginning of 1960s was to normalize relations with Yugoslavia, and not further deteriorate them. His visit to Belgrade in September 1962 meant that the Soviet leadership practically ac-

\footnotetext{
${ }^{24}$ ÁBTL 3.1.5. O-6021/21. 118.

${ }^{25}$ ÁBTL 3.1.5. O-6021/21. 206-208. and 226.
} 
cepted Yugoslavia's special position in international affairs and within the worldwide Communist movement. Therefore, the Soviet-Yugoslav rapprochement and the normalization of Yugoslav-Hungarian relations did not encourage the emigrants' activities. In general, the political activities of ibeovci emigrants in Hungary came to a sudden halt after 1962 as most of the emigrants relinquished from further political planning and withdrew to the privacy of everyday life. However, it did not mean that they accepted Tito's actions in internal and foreign policies or Yugoslavia's own road in building socialism. Therefore, it is not entirely surprising that the small number of emigrants who remained politically active started to sympathize with the ideas of Mao and its European ally, the Albanian Enver Hoxha. ${ }^{26}$ One of them was Obrad Dobanovački who started to organize his own dissident group in late 1967 but his plans came to nothing. The Hungarian authorities rolled up his conspiracy by March $1968 .^{27}$

Even if a tiny fraction of the emigrants remained anti-Titoist in principle in later years, they must have faced the reality that Tito's regime did not collapse even after his death in May 1980. Apart from the lack of financial and material support from other emigrant and oppositional groups and irreconcilable divergence of views within the ibeovci emigrants themselves, other, objective features resulted to the termination of their political activities. Most of them had now been living in exile for 30 or 35 years, became old and lost their political importance. They served as instruments in a geopolitical and ideological game of chess that both parties lost in the long run.

\section{REFERENCES}

- Banac, Ivo. With Stalin against Tito. Cominformist Splits in Yugoslav Communism. Ithaka-London: Cornell University Press, 1988.

- Cvetković, Srđan. Između srpa i čekića. Represija u Srbiji 1944-1953. Beograd: ISI, 2006.

- Cvetković, Srđan. Između srpa i čekića 3. Obrici otpora komunističkom režimu u Srbiji 1944-1991. Beograd: ISI, 2013.

- Cvetković, Srđan. „Politika represije u Srbiji i Jugoslaviji 1944-1985. Pokušaj kvantifikacije i komparacije nekih parametara političke represije u Srbiji i Jugoslaviji 1944-1985". Istorija 20. veka, 2, (2008), 272-315.

- Cvetković, Vladimir Lj. Pogled iza gvozdene zavese. Jugoslovenska politika prema zemljama narodne demokratije u susedstvu 1953-1958. Beograd: INIS, 2013.

- Dragišić, Petar. Jugoslovensko-bugarski odnosi 1944-1949. Beograd: INIS, 2007.

\footnotetext{
${ }^{26}$ ÁBTL 3.1.9. V-154284. 75-77.

${ }^{27}$ For the life and political activities of Obrad Dobanovački in detail see: ÁBTL 3.1.9. V-154284. and Vukman, ,Harcban Tito és Rankovics klikkje ellen”..., 211-220. and 246-250.
} 
- Dragišić, Petar. „Napred - List jugoslovenskih emigranata (pristalica Kominforma) u Bugarskoj”. Tokovi istorije, 3-4, (2005), 125-142.

- Gibianski, Leonid. "The 1948 Soviet-Yugoslav Conflict and the Formation of the 'Socialist Camp' Model”. In: The Soviet Union in Eastern Europe, 194589. Eds. Odd Arne Westad, Sven Holtsmark and Iver B. Naumann, 26-46. New York: St. Martin's Press.

- Gibianskii, Leonid. "The Soviet Bloc and the Initial Stage of the Cold War. Archival Documents on Stalin's Meetings with Communist Leaders of Yugoslavia and Bulgaria, 1946-1948". Cold War International History Project Bulletin, (March, 1998), 112-134.

• Honvári, János. “A hatalmi „elit” jövedelme az 50-es években.” http://archivnet.hu/gazdasag/a_hatalmi_elit_jovedelme_az_50es_evekben.htm 1, downloaded on 25 June $201 \overline{3}$.

- Luburić, Radoica. ,Jugoslovenska informbirovska emigracija između iluzija i stvarnosti (1948-1953)". Istorijski zapisi, LXX, (1997), 1-26.

- Mitrović, Momčilo. „Ibeovci u Srbiji 1948-1952. u partijskim izveštajima”. In: Jugoslovensko-sovjetski sukob 1948. godine. Zbornik radova sa naučnog skupa. Urednik Petar Kačavenda, 223-234. Beograd: ISI, 1999.

- Mitrović Momčilo, i Slobodan Selinić, „Jugoslovenska informbiroovska emigracija u istočnoevropskim zemljama, 1948-1964". Tokovi istorije, 1-2, (2009), 31-54.

- Mitrović, Momčilo. Tri dokumenta o ibeovcima. Beograd: INIS, 2009.

- Perović, Jeronim. "The Tito-Stalin Split. A Reassesment in Light of New Evidence". Journal of Cold War Studies, 2, (2007), 32-63.

- Rajak, Svetozar. "The Cold War in the Balkans, 1945-1956". In: The Cambridge History of the Cold War, Vol. I. Eds. Melvyn P. Leffler-Odd Arne Westad, 198-220. Cambridge: Cambridge University Press, 2010.

- Selinić, Slobodan. Jugoslovensko-čehoslovački odnosi (1945-1955). Beograd: INIS, 2010.

- Shoup, Paul S. The East European and Soviet data handbook. Political, social, and developmental indicators, 1945-1975. Stanford-New York: Columbia University Press, 1981.

- Valuch, Tibor. Magyar hétköznapok. Fejezetek a mindennapi élet történetéböl a második világháborútól az ezredfordulóig. Budapest: Napvilág, 2013.

- Vojtěchovský, Ondřej. Z Prahy proti Titovi! Jugoslávská informbyrovská emigrace v Čehoslovensku. Praha: Univerzita Karlova v Praze, Filozofická fakulta, 2012.

- Vukman, Péter. „Harcban Tito és Rankovics klikkje ellen” Jugoszláv politikai emigránsok Magyarországon (1948-1980). Budapest-Pécs: ÁBTLKronosz, 2017.

- Vukman, Péter. "Jugoslovenski politički emigranti u Mađarskoj (19481949)". U: Mađari i Srbi sa dve strane promenjive granice 1941-1948. Tematski zbornik radova. Urednici Hornyák Árpád, Zoran Janjetović i László Bíró, 351-383. Budapest: MTA BTK Történettudományi Intézete, 2016. 
PÉTER VUKMAN, PhD, Senior Assistant Professor

Institute of History, University of Szeged

Szeged, Hungary

vuximaxi@gmail.com

\author{
SOCIAL COMPOSITION AND EVERYDAY LIVES \\ OF COMINFORM EMIGRANTS IN HUNGARY 1948-1980
}

\title{
Summary
}

As a direct but unexpected consequence of the outbreak of the SovietYugoslav conflict, so-called Cominformist or ibeovci communities were established in the Soviet Union and in its Eastern European satellite states. Their community was organized in Hungary, too, at the turn of 1948-1949. The ibeovci emigrants in Hungary formed a rather small and closed community which was subject to many internal conflicts, personal rivalries, real and imagined grievances. Most of the emigrants arrived to Hungary from the neighbouring Yugoslav republics. Ethnically, the majority of them were Serbs, and socially, they originated from lower social strata. The majority of them originated from the countryside or were first generational town dwellers. The emigrants were also prone to serious hardship in their everyday lives, material and financial conditions, and accommodation. These problems were gradually solved by the mid-1950s. Still, in some aspects, the emigrants lived on at least the same level, or even above the level, of the everyday Hungarians.

Stalin's death and the slow and time-consuming process of normalization between the Soviet Union and Yugoslavia, and consequent improvrmrnt of relations between Yugoslavia and Hungary resulted in the dissolution of the emigrants' community in Hungary in 1954. The emigrants became marginalized and they lost justification for their further political activities, which raised many personal dilemmas. Most of the emigrants remained in Hungary and became apolitical, but a small fraction remained politically active even in the 1960s and 1970s.

KEYWORDS: Soviet-Yugoslav conflict, Yugoslav-Hungarian relationships, ibeovci emigrants, Cominformist emigrants 